August 2012

\title{
The True Measure of Success: The Leadership of Roméo Dallaire in the United Nations Assistance Mission for Rwanda
}

Sarah Devonshire

Follow this and additional works at: https://digitalcommons.usf.edu/gsp

\section{Recommended Citation}

Devonshire, Sarah (2012) "The True Measure of Success: The Leadership of Roméo Dallaire in the United Nations Assistance Mission for Rwanda," Genocide Studies and Prevention: An International Journal: Vol. 7: Iss. 2: Article 5.

DOI: $10.3138 / g s p .7 .2 / 3.184$

Available at: https://digitalcommons.usf.edu/gsp/vol7/iss2/5

This Articles is brought to you for free and open access by the Open Access Journals at Digital Commons @ University of South Florida. It has been accepted for inclusion in Genocide Studies and Prevention: An International Journal by an authorized editor of Digital Commons @ University of South Florida. For more information, please contact digitalcommons@usf.edu. 


\section{The True Measure of Success: The Leadership of Roméo Dallaire in the United Nations Assistance Mission for Rwanda}

Sarah Devonshire

Queen's University

Lieutenant General Roméo Dallaire, as force commander for the United Nations Mission for Rwanda (UNAMIR) and the figure most associated with the infamous mission, has often been accused of providing poor leadership that ultimately failed to prevent the outbreak of genocide in April 1994. To evaluate this claim, it is necessary to analyze Dallaire's actions prior to the outbreak. By looking at his personal suitability, situational nuances, and moments of opportunity during the UNAMIR mission between October 1993 and April 1994, it is possible to form an accurate assessment of Lieutenant General Dallaire's leadership in Rwanda and its relation to the development of the catastrophe. This article will demonstrate that prior to the death of Rwandan President Juvenal Habyarimana, Dallaire succeeded in fulfilling UNAMIR's directives despite resistance on all sides. This assessment disproves arguments that his failure in leading UNAMIR was a primary contributing factor to the outbreak of the Rwandan Genocide.

Key words: UNAMIR, Rwanda, genocide, Dallaire, leadership

\section{Introduction}

Lieutenant General Roméo Dallaire's United Nations (UN) mission to Rwanda is often interpreted through the prism of the genocide that exploded months after the peacekeeping force arrived. The majority of the literature on the mission, including official UN summary publications, has focused on the colonial and pre-1990s national conflicts, glossing over the UN Assistance Mission for Rwanda (UNAMIR) until the onset of the genocide on 6 April 1994. ${ }^{1}$ In this context, the plane crash that killed President Juvénal Habyarimana and marked the beginning of the 100-day massacre became just another step toward chaos for the troubled nation. This paper will argue that this view places undue blame on UNAMIR's military leadership for the genocide's occurrence and disregards UNAMIR's successes prior to the crash when Dallaire was able to manage the evolving scenario and the limitations of the UN mandate with skill and resourcefulness. Until the crash, the situation in Rwanda had been volatile but had presented opportunities for Dallaire and UNAMIR to genuinely further the aims of the Arusha Accords. In the face of numerous stumbling blocks, Dallaire's tenure prior to the crash was a tentative success. Once the plane crashed in Kigali, neither Dallaire nor any other element of the UN had the capability or speed to address and halt the rising tide of genocide. The true measure of his success or failure in Rwanda can only be judged by looking at the days before 6 April 1994.

This argument will establish the criteria by which Dallaire's leadership of the Rwanda mission can be judged a success or failure. With a realistic evaluation of the

Sarah Devonshire, "The True Measure of Success: The Leadership of Roméo Dallaire in the United Nations Assistance Mission for Rwanda," Genocide Studies and Prevention 7, 2/3 (August/December 2012): 184-203. @ 2012 Genocide Studies and Prevention. doi: 10.3138/gsp.7.2/3.184 
resources available and the nature of the UNAMIR mandate, success will be defined as the keeping of peace, the maintenance of the ceasefire, and the facilitation of political processes toward the implementation of the Arusha Peace Agreement. Conversely, a failing mission would be defined by the resumption of large-scale military aggression and the practical inability to facilitate meetings and unified political gatherings. This corresponds with Paul Diehl's suggested criteria for evaluating peacekeeping operations by "how well an operation deterred or prevented violent conflict in its area of deployment; and how much it facilitated 'resolution of the disagreements underlying the conflict."'2

Dallaire's suitability must be evaluated for the peacekeeping mission, but also for the complicated forces at play in Rwanda. Aside from his own suitability, it must also be determined whether any other potential leader had a chance of success, or whether the mission was already troubled prior to his appointment as force commander (FC). Diehl and Daniel Druckerman have raised concerns over the use of the "lessons learned" approach to analyzing peacekeeping, which promotes methods that have worked well in the past with little investigation into why they were effective and whether they are applicable to different situations. ${ }^{3}$ This is very much the attitude that has been used to measure Dallaire's performance. His evaluation in respect to the UNAMIR mission has been based primarily on its final, violent outcome. This argument will instead attempt to analyze his tenure from his arrival until the airplane crash in an effort to understand leadership in peacekeeping missions as more than a matter of responsibility, but as having a unique set of challenges and requirements which need to be further studied and structured in order to strengthen future missions. By looking at pivotal moments to determine whether Dallaire piloted these events toward the best possible outcome, a more accurate measurement of his proficiency as force leader can be formed, and the argument that his leadership was a contributing element to the genocide can be refuted.

Once Dallaire was made force commander, what mission was he to lead? The mandate of the UNAMIR mission is a key element in this appraisal. The mission he believed he was undertaking and the means he understood to be available gave him an image of the mission that would be violently disrupted by the reality of Rwanda. While the situation on the ground changed under his feet, the necessary adaptations to his formal mandate languished in the bureaucratic paper trays of UN Headquarters (UNHQ) in New York. This situation was both a functional and ideological constraint on Dallaire's ability to react and reassess as opportunities as challenges arose.

The obstacles and opportunities that arose during the UNAMIR mission were the showcase of Dallaire's competency as force leader. These scenarios began to shape the progress of the mission before it even touched down in Kigali, and continued to do so until the 6 April 1994 death of President Habyarimana. Beginning with the 21 October 1993 coup in neighboring Burundi and followed by the complications of the Belgian peacekeeping contingent and the deficiencies of the majority of the force, the political concerns surrounding Special Representative to the Secretary-General (SRSG) JacquesRoger Booh-Booh and the informant Jean-Pierre's report of weapons caches in Kigali, Dallaire was confronted with a number of critical moments. The paths he chose and his reactions to obstructions would reveal the true measure of his leadership.

This investigation will look into whether there was still hope that a controlled-if not entirely peaceful-environment could be maintained by the UN force at each 
turning point, and will ask whether the mission was fated to fail before it even began. It will be argued that the possibility of success remained, under the leadership of Dallaire, until the night the presidential jet crashed just outside of the Kigali airport.

\section{Dallaire's Suitability for the Situation}

Evaluating Dallaire's potential for success in the months leading up to 6 April 1994 requires examining his qualities as a leader and, more specifically, his suitability for the role of force commander of the Rwanda mission. Doing so requires firm guidelines for the FC's role in relation to other leaders involved in the mission. ${ }^{4}$ Dallaire's position made him responsible for the military and security concerns of UNAMIR. His superiors assured him that his first peacekeeping mission was to be a "relatively tranquil affair." Matters of politics and diplomacy were assigned to SRSG Booh-Booh. Dallaire was to be subordinate to Booh-Booh, who-as the political leader of UNAMIR-was intended to be a "special representative to lead the mission and provide the diplomatic glue that would make sure the Arusha Accords didn't come unstuck." ${ }^{\text {"I }}$ the fulfillment of the Arusha Accords and the establishment of Rwanda's new government structure, Dallaire's role was to be one of facilitation, not implementation.

This suited Dallaire, who has been described as a "NATO man," implying that his military knowledge had been shaped by the needs of the North Atlantic Treaty Organization (NATO) during the Cold War, rather than a "UN man" experienced in the complex political machinations of peacekeeping operations. ${ }^{7}$ Aware of his inexperience with the political and social elements of UN forces, Dallaire selected Major Brent Beardsleywho at the time was involved in the drafting of the Canadian Forces peacekeeping manual-to assist him and supplement his knowledge of UNHQ and peacekeeping. ${ }^{8}$ Dallaire was not an experienced UN force leader, but he understood himself to be centered in a support network that would supplement his deficiencies in this respect.

Measuring Roméo Dallaire's personal suitability for the Rwandan mission reveals that his deficiencies in experience were mitigated by his suitability to the nature of the conflict. Dallaire's experience with cultural and linguistic plurality in society was ingrained from his youth and the earliest stages of his career. As a young man in Quebec during the era of the Front de libération du Québec (FLQ) Crisis, René Lévesque’s Parti Québecois, and as a bilingual soldier in a predominantly Anglo military, Dallaire was well versed in cultural tensions and prejudices. ${ }^{9}$ He was also experienced in actively navigating and finding solutions to the barriers created by language and ingrained relations. ${ }^{10}$ This was a valuable asset in Rwanda, where the negotiations faltered between the French-speaking Rwandan government forces (RGF) and a largely anglicized Rwandan Patriotic Front (RPF). ${ }^{11}$ Both conceptually and linguistically, Roméo Dallaire was able to comprehend dynamics between the two antagonists that other military figures could not.

These skills were mobilized when SRSG Jacques-Roger Booh-Booh failed to act proactively in his political role. Rather than supplying essential political leadership, Dallaire felt that Booh-Booh was unable to provide any innovation and at times even reasonable aid in response to a volatile situation. ${ }^{12}$ In his own memoir of the UNAMIR mission, Booh-Booh would argue that the lack of movement could be blamed on the intransigence of the Rwandan political class. ${ }^{13}$ Booh-Booh's own publication, a clear attempt at a rebuttal to Dallaire's claims, called this view of his role a "puerile dream" and often chastised Dallaire for his political ventures. ${ }^{14}$ Nonetheless, Dallaire frequently attended the often frustrating political meetings between Rwandans, for which his deputy commander, Henry Kwami Anyidoho, acknowledged him. ${ }^{15}$ He found that his 
language skills led him to act as translator between the English-speaking RPF and French-language representatives of the Rwandan government. He later claimed it was this role as a linguistically neutral figure that gave him greater access and comprehension in Rwanda and motivated communication with all sides. ${ }^{16}$ Faced with a mission leader whom he found at best uninterested and at worst negligent, Dallaire proved that he was not only willing, but particularly well suited to bridging the personnel gaps at UNAMIR's highest levels.

While experience with antagonistic cultural plurality and bilingualism were valuable tools in the Rwandan conflict, they do not single Dallaire out as one uniquely well suited to the mission. Other nations could have provided military leaders with similar characteristics, but what they did not have was the connection to Rwanda found in Canada. Deliberations between the RPF and RGF had identified Canada in particular as a prospective nation from which to draw a peacekeeping commander. ${ }^{17}$ While a Western, bilingual nation, it was free of the colonial history of comparable European states. ${ }^{18}$ Positive impressions of Canada had been developed in Rwanda during the decades after the 1960s decolonization, when Canadian relations with the African nation were tied strongly to education and philanthropy. ${ }^{19}$ These positive bonds made Dallaire a desirable leader for the UN's military force. It also meant that Dallaire was entering an arena where key players had been influenced by his own cultural heritage and experiences.

Considering his linguistic and cultural suitability to Rwandan society, Dallaire seems to have emerged as the most viable candidate for leadership. His own civilian and military experiences fitted him to the organizational and social characteristics of the Rwandan conflict. His character was said to fit well into the African culture, with less cool reserve than many of his anglophone contemporaries. ${ }^{20} \mathrm{He}$ was described as energetic, charismatic, patient, principled, and hard-working, sometimes to the irritation of others, but often to the benefit of his leadership position. ${ }^{21}$

As a leader, he was versed in the realities of modern peacekeeping. When troops under his command were sent to join UN forces in Yugoslavia and Cambodia, Dallaire discovered the vulnerability and possibility of casualties among peacekeepers in regions where conflict continued to spark. ${ }^{22} \mathrm{He}$ recognized this risk in his own mission once on the ground and was subsequently aware of it during his decision-making processes. Dallaire was a man who fit the needs of the situation and culture of Rwanda, had his own knowledge of the dynamics of national conflict, and had a strong career as a military leader.

One of the elements he did lack for an African mission was being from the continent himself. While the UN often tried to give a regional character to African missions, the front-runner for the position, a Nigerian general leading the Organization of African Unity (OAU) observer mission in Rwanda before the UN's arrival, left much to be desired. This officer's own men informed Dallaire during his observations of Rwanda prior to UNAMIR's establishment that the general had abandoned the military observers he had been charged with in the midst of a break in the cease-fire in the de-militarized zone (DMZ), retreating to Kigali and leaving them to fend for themselves. ${ }^{23}$ This was not the strong military figure necessary for a mission that depended as much on its control of minds as its control of bodies. Dallaire was a man who could lead and interact with his own men, and decipher the Rwanda that confronted him.

His primary role was to be the military leader of the UNAMIR force; as such, his military background is an important measure of his suitability for the mission. Dallaire 
was not an experienced UN peacekeeping soldier, nor were his inclinations to be particularly aggressive. In the post-Cold War era, the nature of peacekeeping was beginning to undergo a drastic change. Without the divisive influence of Western-Soviet conflict, new and more complex dimensions were becoming apparent. ${ }^{24}$ Even experienced UN peacekeepers were entering theaters that were unfamiliar and evolving beyond their fields of reference. Criticisms of Dallaire's foundations as an artillery officer are valid for the technical nature of the mission, which was not combat-based or heavily armed. ${ }^{25}$ However, the characteristics of an artillery officer as outlined by the Canadian Forces are highly compatible with the challenges the Rwanda mission produced. The artillery officer was to expect "long hours under stress both by day and night ... to be out of doors with little shelter in all weather, often in physically demanding conditions."26 In response to this environment, artillery officers were expected to perform as superior leaders, especially among subordinates, and to possess physical and mental strength and stamina, methodical and mature judgment, and the ability to perform steadily and quickly while under great stress. ${ }^{27}$ Dallaire's mobilization of these transferable skills from his artillery leadership role to the Rwandan arena shows his suitability as a new leader in a new kind of peacekeeping. His deputy commander Henry Kwami Anyidoho affirmed in his own work on UNAMIR that Dallaire was "a high calibre officer that one rarely comes across ... a courageous leader who showed the way and we all followed."28

As a final measure of his suitability to UNAMIR, Dallaire's resistance to aggressive displays of force was an important feature of his success prior to the outbreak of genocide. While he was not against pre-emptive displays of action or a strong defensive stance, Dallaire's insistence on control among his men was essential in preventing outbreaks of public violence or internal disruptions for months before the crash. From UN force observations and intelligence on Hutu extremists included in Dallaire's cables to the UN, it was evident that the forces of the RGF and its paramilitary organizations were actively agitating an already volatile situation. ${ }^{29}$ RGF elements participated in mass demonstrations during key events in the peace process-armed, but in plain clothes-hoping to incite the crowds and the UN forces protecting politicians. Their aim was to set off violence that would reignite the Rwandan conflict and to target UNAMIR's Belgian troops in order to prompt their withdrawal. ${ }^{30}$ By promoting calm and measured actions and disciplining those who crossed behavioral and disciplinary lines, Dallaire proved that his even temperament and reservation were an appropriate approach in a volatile situation not only prone to violence, but at times specifically working to incite it. ${ }^{31}$

L.Gen Dallaire's strengths and weakness reflect the reality of UN peacekeeping processes. In the United Nations, the force commander and the head of peacekeeping missions are both appointed by the secretary-general. ${ }^{32}$ This detail is not highlighted in order to redirect blame or responsibility for the outcome of missions onto the secretarygeneral, but to raise the question of the need for well-reviewed guidelines in the selection of force leaders. This would likely require matching those individuals selected for their suitability to the mission, such as Dallaire, with the necessary training and guidance in the intricacies of modern peacekeeping that he was not provided with. Such an arrangement would also allow for a greater forum for communication that could build future leaders of peace operations. While Dallaire had proven himself to be a strong leader in the Canadian Forces, there is much that could have been done to support him further as leader of a UN mission. 


\section{Initial Appraisal of the Situation}

In order to understand the character of the UNAMIR mission, it is important to understand Rwanda as it was seen at the time, without the benefits of hindsight, and with a view to Dallaire's responsibilities as a military leader for the UN Department of Peacekeeping Operations (DPKO). Determining whether Dallaire's actions up to 6 April 1994 can be considered successful requires an understanding of what potential for resolution the UN believed existed in Rwanda. If the scenario in Rwanda was massively underestimated prior to commencement, can the standard concept of success as nonviolence and the development of democracy still be applied?

In the 1980s, Rwanda found itself in a position of secure-though not ideal-governance under the dictatorship of Juvénal Habyarimana. For more than 15 years, Habyarimana had ruled over a country which was pragmatically described as "in general one of the least bad in Africa if one considers only its actions and not its intellectual underpinnings." ${ }^{33}$ However, stability fell and racial tensions rose as economic downturns struck the nation. The coffee and tin industries-highly important for the Rwandan economy-collapsed, and the tiny nation became dependent on foreign aid as its main source of income. Leaning on traditional links between Rwanda and France, Habyarimana loosened his monopoly on public power after French president François Mitterrand advised him that democratization was paramount in maintaining a flow of international aid. ${ }^{34}$ While the opening of politics to opposition parties was in keeping with changes being made in many nations following the collapse of the Soviet Union, it stirred up civil conflict in Rwanda. The racialized political tensions between Hutu and Tutsi citizens and exile populations erupted in the early 1990s. Composed largely of exiled Tutsi living as refugees in Uganda after decades of conflict in their homeland, the RPF launched an offensive against the ruling Habyarimana government. ${ }^{35}$ The resultant civil war was the catalyst for international intervention in the African state.

UNAMIR's aim was to monitor the enforcement of the Arusha Accords, the complicated resolution proposed to end the war. Many outside politicians and diplomats believed that these accords presented the best opportunity for establishing a new governance system between the warring factions. ${ }^{36}$ One American representative, Herman J. Cohen, embodied the optimistic view of the UN by stating, in April 1993, that "in terms of the Arusha agreement moving forward, [he] did not consider a nonimplementation scenario." ${ }^{37}$ Much of the UN saw Rwanda as a chance to revitalize its damaged peacekeeping reputation following recent missions in Somalia and Yugoslavia. ${ }^{38}$ In 1993, UN Secretary-General Boutros Boutros-Ghali considered Rwanda "the site of a unique experiment in preventative diplomacy-which was supposed to be the first step in averting war ... and the experiment [was] on the verge of success." ${ }^{39}$ SRSG Booh-Booh was clearly dedicated to the structure of the Arusha agreement and complained that Dallaire did not understand the need to have the confidence of all Arusha signatories, even once the agreement no longer effectively addressed the shifting dynamics of the conflict. ${ }^{40}$ This level of optimism toward a successful Rwandan peace was passed on to Dallaire as the truth of the scenario. In an interview, Dallaire himself stated that the atmosphere at the UN during the formation of his mission plan was decidedly optimistic:

The information we received from the international community and from the UN, who were monitoring and assisting the peace agreement, led us to believe that the mission would be a success. There would be some friction and there was a sense of 
urgency surrounding our deployment. But both sides had come to UN HQ in New York and said that they wanted the peacekeeping mission to happen. It was perceived as a classic low-budget Chapter 6 mission. ${ }^{41}$

A "classic" Chapter 6 peacekeeping mission was based on the idea of the "Pacific Settlement of Disputes" and lacked a Chapter 7 mission's capacity for physical enforcement regarding "Action with Respect to the Peace, Breaches of the Peace and Acts of Aggression." 42 On the direction of the organization sponsoring his efforts and already investigating the conflict, Dallaire initially perceived that his would be an achievable mission in a willing nation.

In reality, Dallaire was not fully informed of the true nature of the Rwandan conflict. A well-trained and respected soldier, he was admittedly not a political specialist, nor was he adequately equipped with one on his initial investigative technical mission. ${ }^{43}$ In a complex political situation with multiple players, the mission lacked adequate political analysis and understanding. The Rwandan nation may have desired peace and stability, but its leaders did not. ${ }^{44}$ Vital information that could have aided Dallaire and altered his mission plan dramatically was withheld or simply not communicated to the DPKO through the often convoluted and competitive structure of UN departments. ${ }^{45}$ A Human Rights Watch report completed in 1993 outlined the trends of violence and rights violations that were already occurring in Rwanda. Even the Network Zero organizationanti-Tutsi "squads" formed across the nation associated with high-level figures like First Lady Agathe Habyarimana and central to the promotion and preparation for the genocide-was specifically identified by observers in the region before Dallaire's arrival. ${ }^{46}$ Despite warnings that any response to the Rwandan situation needed to be properly equipped to address these concerns, Dallaire was not aware of the report until after his return to Canada, after the 100 days of genocide had already consumed the country. ${ }^{47}$ Even the World Bank failed to pass on vital information about Rwanda's militarization to the UN, considering it unnecessary to inform the Security Council of its knowledge of arms shipments arriving into the country. ${ }^{48}$ This lack of information likely influenced Dallaire's determination that while a mission force of 5,500 would be ideal, a "reasonable viable option" of a 2,500-strong force could still complete the mission while passing the UN's austere approval standards for mission size and cost. ${ }^{49}$ It was with this dearth of knowledge and barely adequate force strength that Dallaire would face the challenges of Rwanda. If he was to succeed, he would have to do so with a less-than-ideal force in a scenario more complex than he could have known. This was the challenge Dallaire faced from his arrival on 22 October 1993 to the night of 6 April $1994 .^{50}$

\section{Crisis Point}

To understand why an investigation into Roméo Dallaire's success must begin before April 6, the plane crash that resulted in the death of President Habyarimana must be clearly understood as the critical fracture point in the Rwandan conflict. The event and its direct repercussions removed Dallaire's ability to act in any meaningful way toward the establishment of peace. A survivor of the genocide focused the restricted nature of Dallaire's response on the rising tide of violence after the crash:

We wondered what on earth UNAMIR was doing in Rwanda... . [They] could not even lift a finger to intervene and prevent the death of tens of thousands of innocent people who were being killed under their very noses. . . An institution must have the capacity to be effective. But the UN protects no one. ${ }^{51}$ 
While some have stated that UNAMIR's "greatest challenge" was to stop the killings, in reality this was neither its purpose nor within its ability. ${ }^{52}$ Dallaire had not been sent to Rwanda to fight for peace, only to facilitate it. He would later recall that in the face of the rising violence "UNAMIR's hands essentially remained tied." ${ }^{33} \mathrm{He}$ posited that if he had been provided with a contingent able to convince Rwandans it was "riskier to go [out] . . . than stay at home, we could have stopped it." ${ }^{54}$ Unfortunately, the reality of UN dynamics and logistics made the plausibility of this a moot point. If providing a monitoring force during ceasefire was considered impractical by the US or UK, volunteering troops when the element of risk escalated was too foolish to even consider. Unwilling to increase support in the months prior to the crash, the UN certainly would not send in troops after it. ${ }^{55}$

Habyarimana's death irreparably destabilized the nation. Ignace, a Hutu interviewed by author Alain Destexhe during his post-genocide research in Rwanda, was one of the many génocidaires who rose from the wreckage of the crash. He recalled the new, collective sentiment that formed following it. ${ }^{56}$ Ignace told of a radical Hutu element that "no longer worried about who had followed the teachings of the presidential party or the teachings of a rival party. We forgot all quarrels, and who had fallen out with whom in the past. We kept only one idea in the pot." ${ }^{\prime 5}$ That idea was genocide.

This was mirrored in the international connections around the Rwandan peace settlements. Habyarimana was the conduit between Rwandan politics and the international community. ${ }^{58}$ The inflammatory Hutu radio station Radio Télévision Libre des Milles Collines (RTLM) encouraged the public to "stand up, take action . . . without worrying about international opinion." ${ }^{59}$ Many did just that. A witness to the genocide later revealed that the violence "did not become widespread until extremists saw the world would not get involved and that UNAMIR's contingents would protect only themselves." ${ }^{60}$ Hutu radicals were no longer held back by the influence of the international community embodied in an established leader or UNAMIR. Habyarimana's death released the ties that had kept intent from becoming action. ${ }^{61}$

Colonel James Allen, who had led peacekeeping missions before retiring from the military to become a journalist, shamed Dallaire. He chastised him for not diving into the conflict in the "best military tradition," which would have been tantamount to suicide for his troops, yet at the same time criticized him for allowing the deaths of the Belgian soldiers on security detail with Prime Minister Madame Agathe. ${ }^{62}$ Allen argued that Dallaire's Canadian contemporary, Major-General Lewis MacKenzie, chief of staff in the 1992 UN mission in Yugoslavia, would not have failed as he believed Dallaire had. ${ }^{63}$ Yet, in his contradictory disapproval of both action and inaction, it is hard to determine what outcome he would have considered a success. Deputy Commander Anyidoho later reinforced Dallaire's pragmatic stance, questioning the wisdom of placing UN forces "with basically only personal weapons ... in the face of belligerents who were armed to the teeth." 64 While morality obligated action, it was not a practical or political possibility in Rwanda in 1994. The flood gates had been opened and no one man, whether willing or recalcitrant, masterful or inept, could close them.

\section{Mandate}

The UN's approval of Dallaire's proposal for a force of 2,500 led to the creation of the mission mandate for UNAMIR. However, it was not the only outline that would be created in the early months of the mission. The political and military settlement in Rwanda had been created through the Arusha Peace Accords, the heavily debated peace 
agreement made in Arusha, Tanzania, between the RPF, RGF, and other Rwandan parties. ${ }^{65}$ The Arusha Accords called for a neutral international force to assist in implementing the new government structure and maintaining the unsteady truce between the sides. However, the creators of the accords recognized to a greater degree that "peacekeeping cannot be an end in itself-it merely buys time." 66 African politicians and insiders were becoming aware that the possibility of force would be a vital element to any response. However, the response they wanted and the force they received had considerable differences. Arusha outlined a mission which would have secured the country as a whole, taken part in actions such as arms confiscations, and enforced security. Both unwilling and unable to find funding or willing participants, the UN watered down these strong aims, cutting down the geographic reach and the force's bite, replacing confiscation with mediation, and security with monitoring. ${ }^{67}$ The UN mandate consisted of eight roles for the UNAMIR force:

a. to contribute to the security of the city of Kigali, inter alia, within a weapons-secure area established by the parties in and around the city

b. to monitor observance of the cease-fire agreement ...

c. to monitor the security situation during the final period of the transitional Government's mandate, leading up to the elections

d. to assist with mine clearance, primarily through training programmes

e. to investigate ... instances of alleged non-compliance with the provisions of the Protocol of Agreement on the Integration of the Armed Forces of the Two Parties, and to pursue any such instances with the parties responsible and report ... as appropriate to the Secretary-General

f. to monitor the process of repatriation of Rwandese refugees and resettlement of displaced persons...

g. to assist in the coordination of humanitarian assistance activities ... with relief operations

h. to investigate and report on incidents regarding the activities of the gendarmerie and police $^{68}$

The primary intent of the mandate was to monitor and assist the Rwandans in their progress toward a peaceful settlement. While the mandate initially appeared to be a sufficient outline for the simple mission the UN believed Rwanda to be, in truth the situation was much more complex than the mandate recognized.

The mandate itself presented numerous problems. It was formed at a time in 1993 when the DPKO's perception of Rwanda was simplistic and uncomplicated. As such, Dallaire did not consider the exact semantics of the mandate to be of great importance. Without the anticipation of active and widespread violent elements in Rwanda, it was not important that the specific wording could eventually prevent UNAMIR forces from engaging with violent mobs or individuals. ${ }^{69}$ Due to these expectations, the mandate was also formulated around traditional perceptions of peacekeeping operations. It presupposed goodwill, respect, and cooperation from both sides of the conflict so that UN forces could remain a neutral force between them. ${ }^{70}$ When this was discovered to be untrue, the need to institute flexibility into the mandate to address the shifting situation on the ground was heightened. ${ }^{71}$

Further, the generic quality of the mandate gave Dallaire a wider impression of his options than the UN had conceived. In an interview, Dallaire spoke of 
the impasse over philosophy and interpretation of the mandate. I saw my mandate as "6-plus," which gave me a certain amount of room for manoeuvre. DPKO saw it in a much more restrictive sense, because of the fear of casualties and so on. ${ }^{72}$

In the spirit of a "six-plus" mandate that gave room for military actions in the face of threats to human rights, Dallaire produced the guiding document for UNAMIR that elaborated on the outline in the mandate: his rules of engagement (ROE). In UN operations, the ROE are written by the commanding officer after the establishment of the mission. Upon reaching this stage, Dallaire took what he perceived to be the open spirit of the mandate and shaped his Rules to fit his scenario. He saw it as his general role to "create an atmosphere of security," and to do so, he recycled a portion of the Cambodian peace-enforcement mission's text, which became paragraph 17 of the ROE. ${ }^{73}$ Paragraph 17 stated that the occurrence of crimes against humanity "morally and legally [required] UNAMIR to use all available means to halt them." ${ }^{74}$ Dallaire believed that this was within the boundaries of his vague mandate, and necessary in light of recent developments in Rwanda. The UN never responded to his ROE, neither positively or negatively, and Dallaire took this as a tacit approval of his direction. ${ }^{75}$

\section{Crossroads}

Evaluating Roméo Dallaire's leadership of the UNAMIR mission prior to 6 April 1994 requires a specific area of investigation. For this analysis, the most important evidence is in the decisive moments when conflict in Rwanda and the mission determined in which direction UNAMIR and the nation would go. Dallaire's ability to lead a successful mission rested less on the stasis of peace, and more on the resolution of conflicts that threatened it. By investigating these moments of conflict and their results, it is possible to evaluate the point at which the mission was or became irredeemable.

\section{Burundi Coup}

The first crisis that Dallaire faced during the UNAMIR mission arose as he touched down in Kigali. Arriving on 22 October 1993, Dallaire found that the very fundamentals of Rwanda's national situation had changed drastically the day before. ${ }^{76}$ Along the southern border of the country lay Burundi, with its own postcolonial legacy of Hutu and Tutsi conflict. The day before Dallaire's arrival, leaders in the nation's Tutsi-led army overthrew and assassinated Hutu president Melchior Ndadaye, who had been recently elected in Burundi's first free elections after 30 years of Tutsi dictatorship. ${ }^{77}$ This coup had several repercussions on the Rwandan situation. In the wake of reprisals from Hutu and Tutsi, 300,000 mostly Hutu refugees crossed the border to camps in southern Rwanda. ${ }^{78}$ For Hutu in Rwanda, fears of Tutsi hegemony were escalated by the coup, providing not only the spark, but also fuel for the fire of charged opposition. Theories of an overarching Tutsi plot were enflamed by radical propaganda that warned against believing that "what happened in Burundi cannot happen here."79 Large Hutu refugee populations in the south proved to be fertile recruiting ground for the RGF, where "Hutu Power" grew in a climate of the Hutu nation under siege. ${ }^{80}$ The lack of Western reaction and recognition of the Burundi crisis was also compelling evidence to Rwandans of the limitations of international intervention. ${ }^{81}$ The upset in Burundi did not only remove the secure southern front Dallaire had depended on, but it also agitated the conflicts and tensions in Rwanda just in time for his arrival. 
This was a key moment for Dallaire's leadership. He recognized immediately that "everything had changed. Not only would the coup in Burundi shake the fragile political situation in Rwanda, but the stable southern flank, which I had relied on in my mission plan, had vanished." 82 As his first test, it was important to set a precedent while reshaping his understanding of the atmosphere. It was essential that the mission did not run out of hand within its first days. In response, he reorganized according to the increased security requirements. Dallaire immediately requested an increased force from the UN. The DPKO informed Dallaire that the troops were not requested in the initial mission report, filed before the coup had occurred, and as such would not be added on at that point. ${ }^{83}$ Establishing an element of stability in southern Rwanda would require the juggling of his already limited personnel to a region he had not intended to staff heavily. Dallaire stretched his force of unarmed military observers into the south to maintain UNAMIR presence throughout the unsettled nation. ${ }^{84}$ Determined to make higher powers aware of the heightened tensions, Dallaire continued to report to the UN that the stretching of UNAMIR's forces in this new environment would require taking more risks. It was not ideal, but it was a reality he was willing to work with. In his reports, Dallaire gave a realistic but positive look at the situation and needs, recognizing his responsibility to protect the Rwandan peace and his own contingent. It was not until after the mission that he found out that SRSG J. R. Booh-Booh had watered down his expressions of concern to a picture of slow and steady progress before allowing them to reach the UN. ${ }^{85}$ At the time, Dallaire was painted as a cowboy and Booh-Booh's reports were considered more balanced and understanding of the situation. ${ }^{86}$ In the aftermath, it would appear that these perceptions were not an accurate representation of events.

The situation in Rwanda at this time was not out of hand. Radicals did not take advantage of the chaos in Burundi to mount their own political or military action in Rwanda and Dallaire was able to establish a monitoring force that fulfilled UNAMIR's needs in the south. While tensions had been raised and racial rhetoric spread, it was not obvious at that point that widespread genocidal chaos would ensue as a direct result.

\section{Force Dynamics}

Dallaire's second challenge arose with the arrival of the various national groups that formed the UNAMIR forces. Without the support of large nations such as Great Britain or the United States, the UNAMIR contingent was composed largely of forces from smaller nations in Asia and Africa. The only significant Western elements were the Belgians. While their skills and experience were essential to the success of Dallaire's mission, they had their own complications. They arrived with limited supplies and equipment, although more than other contingents, and fresh from assignment in the Somalian conflict. When further equipment did arrive, the long distances involved in their transportation to Rwanda left most machinery and vehicles broken and stripped of vital components. ${ }^{87}$ Furthermore, the colonial history of Belgium as an oppressive power in Rwanda made their contribution to the force controversial at best. Dallaire was faced with the added complication of dealing with Belgian para-commandos fresh from active conflict in Somalia and used to peace enforcement, not peacekeeping. ${ }^{88}$ Their attitude and the environment they were accustomed to encouraged aggressive behavior that did not mesh with UNAMIR's methods. However, as his only significant Western force, Dallaire needed the Belgians as a controlling and secure influence in a complex environment. Dallaire would become aware in the course of the following months that the Belgian soldiers were specifically targeted for agitation by radicals trying 
to get Belgium to withdraw from the force in the face of casualties. ${ }^{89}$ They were a target for disturbances and worsened the situation by actively creating problems for the mission. The best example occurred when the Belgian protective detail supporting the transit of RPF representatives to Kigali abandoned them in the face of attack. Dallaire reported that the "shame this incident brought on UNAMIR forces was never expunged." 90 The Belgian contingent was both a blessing and a curse to Dallaire and to UNAMIR.

The majority of UNAMIR's forces were provided by poorly prepared and undersupplied "Third World" nations. These soldiers were promoted as "highly motivated, if less well trained." ${ }^{91}$ In reality, many arrived with broken or outdated equipment, little to no supplies, and without the training or desire to meet UNAMIR's challenges. ${ }^{92}$ For Dallaire, the Bangladeshi contingent was the epitome of this conundrum. Contributing nations were required to supply their troops with sixty days of supplies. The Bangladeshis came without many of the most basic requirements for food and shelter. This was particularly striking when considering that the Bangladeshi contingent made up the majority of logistical support units for the mission, including the engineering and medical services. Dallaire's deputy commander Henry Kwami Anyidoho of Ghana had warned him against depending on a developing country to serve as a central element of UNAMIR's logistics, but Dallaire countered that Bangladesh was also the only nation that had offered. ${ }^{93}$ When he tried to train them as a quick-response force, they proved unequal to the task, more likely to escalate than improve a high-risk scenario. ${ }^{94}$ In periods of tension, Dallaire would discover that they and other contingents would operate according to orders issued by their country, not by UNAMIR. ${ }^{95}$ The Bangladeshis and other, similar force contingents created a constant juggling act for Dallaire to monitor, supply, and control in the sparse time available outside the maintenance of the mission's basic requirements.

In response to these challenges of mission leadership, Dallaire was able to assess both his personnel and his environment in order to juggle the complex force dynamics. When the Belgians lost RPF confidence after Belgian soldiers abandoned their duties, Dallaire modified the placement of his contingents. Instead of the controversial Belgians, the well-trained Tunisian force was positioned at the RPF headquarters in Ki-

gali. ${ }^{96}$ Dallaire was also able to use general Belgian presence and participation to the benefit of the mission, calling on Belgian personnel for intelligence information that UNAMIR itself lacked. Such changes revealed some flexibility in UNAMIR that allowed Dallaire to react to challenges. His was a responsive force, not one locked in a downward spiral.

Dallaire also revealed himself to be willing to make difficult decisions for the overall success of the mission. In response to Belgian forces' fraternization in Rwandan bars and with Rwandan women, their aggressive attitude toward Rwandan politicians and important figures, and general insubordination, Dallaire went to the Belgian command, threatening that control had to be established or the continuation of a Belgian presence would become a greater hindrance than help to UNAMIR. ${ }^{97}$ Several Belgian soldiers were removed to Belgium in the face of their actions. ${ }^{98}$ It is difficult to believe that Dallaire would have been willing to even consider the removal of the Belgian contingent force if he had thought that large-scale violence was about to break loose across Rwanda.

\section{Political Deficiencies}

With the establishment of the UN mission in Rwanda, attending to the political requirements of the Arusha agreement became a primary concern. Dallaire was aware of his 
position as a military man and hoped that UNAMIR requirements beyond his expertise would be handled by an effective ally. Dallaire wanted this ally, the special representative to the secretary-general, to be a military figure who would lead a French-language mission in Rwanda. In reality, he received a civilian, Cameroonian Jacques-Roger Booh-Booh, and a mission with English as the operational language in a primarily French-speaking region of Africa. ${ }^{99}$ Booh-Booh was supposed to be the "glue" that kept the Arusha Accords together, but for Dallaire he was often more divisive than effective. ${ }^{100}$ Though the SRSG was a confidant to then UN Secretary-General Boutros Boutros-Ghali, he also refused to use his influence to aid the mission. ${ }^{101}$ Seemingly favorably biased toward the former Rwandan government and often damaging to the vital image of UN neutrality with his numerous personal visits with President Habyarimana, Booh-Booh's fit with the Rwandan mission was awkward at best. ${ }^{102}$

Politically, Dallaire found Booh-Booh's diplomatic efforts limited and filled with ultimata and threats toward both sides of the civil conflict. His communications with the UN were full of watered-down appraisals and assurances that contributed to a regular pattern of denial to Dallaire's requests, even when tensions escalated. ${ }^{103}$ According to Dallaire, at one fragile point in February 1994 during political discussions between the parties to form the new government, Booh-Booh "suddenly pounded the table . . . and got up, knocking his chair over in his haste. This meeting was going nowhere, he announced emphatically, and he was not going to waste any more of his time. In fact, he refused to chair any more such meetings." ${ }^{104}$ Deputy Commander Anyidoho stated a belief that Booh-Booh's missteps, including his visits with Habyarimana, were done in innocence of their harm. ${ }^{105}$ As the senior political figure for the mission and the supposed diplomatic head of UNAMIR on the ground, it would seem that Booh-Booh should have had the foresight to understand the implications of his actions in a delicate political situation. An interview allowed Dallaire to reflect on Booh-Booh's position as the figurehead and political leader of UNAMIR:

Booh-Booh was given the task of leading the process, but he was never able to bring forth innovative ideas. Indeed he seemed, at times, to not be particularly helpful in bringing along possible solutions. ... Looking back, it would have been interesting to have had a political advisor-rather than a political boss-a solid, experienced diplomat-politician . . . with whom we could have built a team. ${ }^{106}$

Booh-Booh would later attempt to contradict this image of himself by arguing that an arrogant Dallaire struggled under the authority of an African. ${ }^{107}$ There were no such similar claims from Dallaire's other African counterparts.

Dallaire's response to Booh-Booh's limitations would reveal both his adaptability and his continuing belief in the viability of maintaining the Arusha process. He couldn't overpower Booh-Booh's influence at the UN to argue for the primacy of his mission's needs. Instead, Dallaire attempted to fill the diplomatic gap to the best of his own ability. ${ }^{108}$ He held and participated in political meetings in an attempt to break deadlocks on cabinet assignments to the broad-based transitional government (BBTG) proposed by the Arusha Accords ${ }^{109}$ :

I attended all the political meetings (as the number two of the mission) as the Force Commander, so not only was I sitting at the table with the SRSG and attempting to 
whisper comments, etc., but I also often found myself being the translator between the English-speaking RPF and the French-speaking government representatives. Consequently, a number of people-extremists, Tutsi and Hutu moderates, and so on-would conduct overt and covert meetings with me. ${ }^{110}$

Dallaire's dedication evidences his belief that Arusha was not a lost cause in the early months of 1994 . His attempts at politics contributed to the continual efforts to resolve those issues involved in installing the BBTG. In his own book on UNAMIR, Deputy Commander Anyidoho recognized the difficulties involved for military leaders unable to avoid political machinations during a civil conflict and the way in which peacekeepers, including Dallaire, had to be ready to "face all these frustrations to the point of being humiliated." ${ }^{111} \mathrm{He}$ would go on to recommend that in recognition of this emerging challenge, diplomacy become part of the training given to potential peacekeeping soldiers and military leaders. ${ }^{112}$ Under the auspices of UNAMIR, attempts were made to further the government's formation on January 1, January 5, February 14, February 23, March 25, March 28, and in early April 1994. ${ }^{113}$ While it was a frustrating situation for Dallaire, who admitted he was no expert in political machinations, an overt consensus on Rwanda's descent toward destruction did not dominate UNAMIR.

\section{"Jean-Pierre" and Kigali Weapons Caches}

A galvanizing possibility for UNAMIR arose in mid-January when Dallaire was presented with the testimony of an RGF informant code-named "Jean-Pierre." He claimed to be a military trainer who was preparing elements of a national militia, the Interahamwe, for acts of mass violence. ${ }^{114} \mathrm{He}$ gave specific information on the location of arms caches in Kigali that were intended for distribution. Dallaire saw this information-which was verified by a member of the contingent who was shown the cache by Jean-Pierre-as a golden opportunity. ${ }^{115} \mathrm{He}$ directly informed the DPKO of his plan to conduct a raid on the cache, bypassing the SRSG. Believing that the cache was in direct violation of the Kigali Weapon Secure Area (KWSA), a key element to Arusha and UNAMIR, Dallaire considered this action to be well within his mandate. The message to the DPKO was intended as a notice of action, not a request for approval. ${ }^{116}$ In likely the fastest response from New York during the mission, a direct notice from DPKO heads Kofi Annan and Iqbal Riza forbade the raid. ${ }^{117}$ Dallaire was not only told that this would be in violation of his mandate, but he was instructed that for the purposes of transparency, he had to inform President Habyarimana and his advisors of the information. ${ }^{118}$

The action Dallaire was forbidden to take could have been a key stabilizing element in the Rwandan conflict. In a post-conflict analysis published by the Pearson Peacekeeping Centre and including input from an OAU report, it was argued that the "power of presence," the psychological impact of a force beyond their physical strength, should not be underestimated in situations like Rwanda. ${ }^{119}$ The report of UNAMIR knowledge of the caches turned out to be a shock to the president and his associates. ${ }^{120}$ The seizure of the weapons could have had a considerable impact, projecting a more powerful image of UNAMIR and international control in Rwanda. Instead, the surprise exhibited by the RGF quickly receded and the distribution of arms from the cache was accelerated as a result. Dallaire was frustrated by the prohibition on conducting arms raids, which he believed satisfied the original mandate's requirements for the establishment of KWSA and contributions to the security of Kigali. Public knowledge of other caches 
and expectations that UNAMIR would address them aggravated this further. ${ }^{121}$ It had been an ideal opportunity to gain a grip on the security situation in Kigali. Dallaire would later learn that his warnings had failed to reach the highest levels of the UN, including Secretary-General Boutros Boutros-Ghali, a move that would come to be considered by some an "incomprehensible" disgrace to the UN structure. ${ }^{122}$ Others considered it a failure by Dallaire for not sending the message directly to the highest levels, even though he was already breaking protocol in bypassing Booh-Booh and sending it directly to the DPKO. ${ }^{123}$ In retrospect, Dallaire's intentions looked to head off problems that might arise in the future. Yet the disavowal of pre-emptive action was still not a death sentence to the peace process.

In the period that followed Jean-Pierre's revelation, Rwanda did not appear to be facing a downward spiral into mass violence. Violence in February was followed by a period of calm in March that precipitated the continuation of political discussions. ${ }^{124}$ Dallaire was aware of the threats radical groups posed, yet "despite increased tensions and insecurity engendered by the political impasses, the cease-fire was generally holding. UNAMIR forces . . . continued to play a stabilizing role." ${ }^{125}$ Even some Rwandan politicians were cautiously optimistic. In March 1994, Moderate Faustin Twagiramungu expressed a belief that the only thing that could possibly stop the Arusha agreements was a decision by President Habyarimana. ${ }^{126}$ The comment would become surprisingly prescient. The day before the crash, UN Resolution 909 of 5 April 1994 "[welcomed] the fact that, despite the difficulties encountered in implementing the Arusha Peace Agreement, the cease-fire has been respected and commends in this respect the essential contribution made by UNAMIR." 127 The UN did not yet see that their forces were stuck in a futile situation and in need of withdrawal. Even though the opportunity provided by Jean-Pierre's information was missed, it did not appear that the extreme violence of the coming days and weeks was a foregone conclusion at this time.

\section{Conclusion}

Three dynamics are vital to making any judgment about Dallaire's performance in Rwanda; the first is his personal and professional suitability to the mission; the second, the evolving structure of UNAMIR; and the third, his response to key crossroads during the development of the mission. However, these three dynamics must be considered within specific parameters. The plane crash that killed President Juvénal Habyarimana and precipitated the eruption of violence and genocide is the cut-off point of this investigation. After this point, it can be seen through an examination of the changes in circumstance, power, and politics in Rwanda, and the guidelines of the UNAMIR mandate, that Dallaire had neither the ability nor the authority to respond to the widespread chaos. This is not to limit the importance or gravity of the genocide that would follow, but to produce an examination of the UNAMIR mission and specifically Dallaire's leadership that is not biased by the moral responses formed in the aftermath of the genocide. The literal decimation of Rwanda at its own hands was watched by a world which cried out at the failure of international forces to stop the flow of blood, the same world that neglected the efforts to stabilize it, only to then cast it as a catastrophic failure. Upon examination, there is much more to the legacy of the United Nations Assistance Mission for Rwanda than the 100 days of genocide in 1994. As a military leader, Roméo Dallaire had six months of operation during which he maintained an uneasy peace with a limited pool of resources to draw from. As other peacekeeping analysts have argued, it may be better to look at the methods and means of Dallaire's 
leadership that worked and why, rather than the destructive conclusion the country ultimately came to.

Dallaire's suitability to the Rwandan situation provides the basis for examining his effectiveness. A leader, no matter how dedicated or capable, can be hindered by the nature of his approach or lack of environment-specific skills, such as language or cultural knowledge. For Rwanda, Roméo Dallaire would prove himself to be an effective fit for an unusual situation. His background, not only as a military officer, but as a FrenchCanadian integrated into a largely anglicized environment of the Canadian Forces made him familiar with concepts of minority populations, bilingualism, and cultural prejudices so predominant in Rwanda. Although he was inexperienced with UN missions and his suitability for the position as an artillery officer was questioned, Dallaire gathered others with experience into his team for support and used the transferable skills from his artillery position to adapt to the rigors of Rwanda. In addition, the value of experience in UN peacekeeping missions in the past, which Dallaire did lack, was complicated by the rapidly changing character of peacekeeping in the immediate post-Cold War period. The scenarios UN veterans had faced were often vastly different from the situations they began to find themselves in. His nationality was also a particularly good fit for a mission in Rwanda, as the country's relations with Canada lacked the specters of colonialism that European nations represented, and charitable and educational works had developed a positive impression of Canada since decolonization. Dallaire, as a French Canadian, arrived to find that many leading figures were directly tied to his own nation, province, and culture in a way few others could have appreciated. These strengths would be vital to Dallaire in an environment with few other suitable candidates and little support from the UN's political elements in Rwanda and New York.

The structure of the mission reveals both the strengths and weaknesses of the system upon which Dallaire depended. The inflexibility and ambiguity of the mandate in response to a rapidly changing situation on the ground limited the requests Dallaire could make and the actions that he could take. The complications of the UN's interdepartmental rivalries and disconnects further hampered Dallaire by depriving him of information on Rwanda, including arms movements and human rights violations, that would have been vital elements of the mission's primary evaluations. Requests for additional forces, supplies, and support were denied, communications unanswered, and Dallaire was left to assume that in his approach to the situation and interpretations of his options, no news could only be good news. This situation reveals a great deal about Dallaire's determination and the dedication of many members of the UNAMIR mission to keep it operational, while at the same time revealing the betrayal by UN officials who were meant to be supporting them.

Ultimately, the means to judge Dallaire's leadership and success in Rwanda in the period prior to the crash is the examination of his decisions at key crossroads. These responses reveal whether the mission of maintaining ceasefire and facilitating political development was still viable. The first challenge arose with the coup in Burundi, which negated the calm southern front Dallaire had depended on in his mission plan. Despite the contagion of unrest present in the first days of the mission, Dallaire was able to reallocate his forces and begin the planned initiation of UNAMIR on the ground. In establishing the mission, he would be challenged by complications caused by force dynamics and personnel deficiencies. The complications of poorly provisioned or ill-suited troops marred the military element and required regular adjustments and reassignments to 
maintain the security and ceasefire of Kigali and Rwanda. The reticence of the political head of the mission, SRSG Jacques-Roger Booh-Booh, forced Dallaire to act as a political liaison at many turns, a role beyond his military position and training, but vital to the overall mission. Dallaire's greatest test would come with the informant Jean-Pierre. While potential raids on weapons caches within the KWSA were forbidden by the UN DPKO hierarchy and may have ultimately been numerically insignificant, the action that Dallaire aimed to respond with emphasizes a very different perspective. The planned raid could have depicted Dallaire as a potential man of action in Rwanda and made a huge contribution to UNAMIR's image and control in the region. In a position hindered by the realities of UN supply issues and mission restrictions, this image was one of Dallaire's strongest tools. The decision of the DPKO to forbid the raid struck a blow to UNAMIR's perceived effectiveness but did not make it a wholly lost cause.

The UNAMIR mission and the Rwandan genocide are inextricably tied together in memory as part of an incomprehensible tragedy. In the face of this, the simplest way to deal with the aftermath was to find a scapegoat who could be blamed this "failure of humanity." A closer analysis of the situation and the environment, both in Rwanda and across the international stage, reveals a different story. Investigating the mandate and mindset of the mission, it can be seen that the outbreak of civil war negated the role of the forces that were there as peacekeepers, not peace enforcers. UNAMIR and the genocide were unavoidably separated by the crash of President Habyarimana's plane, and as such, Roméo Dallaire's leadership of the UN mission can best be judged in the period from his arrival on 22 October 1993 to the crash at the Kigali airport on 6 April 1994. Not only for Dallaire, but for the study of peacekeeping, it is of greater use to understand these months of stability, rather than the ultimate conflagration. It is during those months, when tensions and strains could have lead to a renewal of violence at any time, that Dallaire's effectiveness as a peacekeeper can be seen. His actions revealed a suitability, resourcefulness, and resilience that pushed the nation toward the process of peace, or at least barred the way to widespread chaos. When the president's plane went down, it took many things with it. A storm of unstoppable events swelled within the nation as the mission's mandate was destroyed. Neither Dallaire, nor the slow-moving UN, nor the unwilling, powerful nations of the world could stop what had begun. The genocide was a current that swept up everyone within the nation, and destroyed any evidence of progress in Rwanda, leaving Dallaire vulnerable in the public eye. That narrative ultimately fails to tell the whole story of the UNAMIR mission. Rwanda may have been a failure of humanity, but it was not Dallaire's failure alone.

Sarah Devonshire received her BA and MA from the University of Toronto and Queen's University respectively. Her focus is on the history of twentieth-century conflicts and genocide, including Rwanda, the Holocaust, and the creation of the UN Genocide Convention. She currently lives and works in Toronto, Canada.

\section{Notes}

1. For examples of this trend, see Philip Gourevitch, We Wish to Inform You That Tomorrow We Will Be Killed With Our Families: Stories from Rwanda (New York: Farrar, Straus, and Giroux, 1998); Gérard Prunier, The Rwanda Crisis: History of a Genocide (New York: Columbia UP, 1995); and Scott Peterson, Me against my Brother: At War in Somalia, Sudan, and Rwanda; A Journalist Reports from the Battlefields of Africa (New York: Routledge, 2000).

2. William J. Durch, UN Peacekeeping, American Politics, and the Uncivil Wars (Basingstoke: Macmillan, 1997), 17. 
3. Paul F. Diehl and Daniel Druckman, Evaluating Peace Operations (Boulder, Colorado: Lynne Rienner, 2010), 5.

4. Organisation for Economic Co-operation and Development, Development Centre, Larry Minear, and Philippe Guillot, Soldiers to the Rescue: Humanitarian Lessons from Rwanda (Paris: Organisation for Economic Co-operation and Development, 1996), 46.

5. OECD et al., Soldiers to the Rescue, 91.

6. Carol Off, The Lion, the Fox \& the Eagle: A Story of Generals and Justice in Yugoslavia and Rwanda (Toronto: Random House Canada, 2000), 27.

7. Ibid., 21.

8. Roméo A. Dallaire and Brent Beardsley, Shake Hands with the Devil: The Failure of Humanity in Rwanda (Toronto: Random House Canada, 2003), 45.

9. Ibid., 19-20, 22-4, 72 .

10. Ibid., 34 .

11. Ibid., 72 .

12. Richard Cobbald, “Interview with Roméo Dallaire," The RUSI Journal 150, 5:25.

13. Jacques-Roger Booh-Booh, Le patron de Dallaire parle: révélations sur les dérives d'un général de l'ONU au Rwanda [Dallaire's boss speaks: revelations about the excesses of a UN general in Rwanda] (Paris: Duboiris, 2005), 202.

14. Ibid., 94.

15. Henry Kwami Anyidoho, Guns over Kigali (Accra: Woeli, 1997), 19.

16. Cobbald, "Interview," 26.

17. Off, The Lion, the Fox \& the Eagle, 25.

18. Dallaire and Beardsley, Shake Hands, 61.

19. Christian P. Scherrer, Genocide and Crisis in Central Africa: Conflict Roots, Mass Violence, and Regional War (Westport, Conn.: Praeger, 2002), 200; Off, The Lion, the Fox \& the Eagle, 15

20. Off, The Lion, the Fox \& the Eagle, 30.

21. Ibid., 35; Linda Melvern, A People Betrayed (Halifax, NS: Fernwood, 2000), 83.

22. Dallaire and Beardsley, Shake Hands, 41.

23. Ibid., 86.

24. Diehl and Druckman, Evaluating Peace Operations, 7.

25. Off, The Lion, the Fox \& the Eagle, 107.

26. "Officer Trades," 34 Canadian Brigade Group, National Defence and the Canadian Forces, last updated 23 May 2012, http://www.army.forces.gc.ca/34cbg_hq/metieroffren.aspx (accessed 13 Oct 2009).

27. 34 Canadian Brigade Group, "Officer Trades."

28. Anyidoho, Guns over Kigali, 60.

29. Howard Adelman and Astri Suhrke, The Path of a Genocide: The Rwanda Crisis from Uganda to Zaire (New Brunswick, N.J.: Transaction, 1999), xxi.

30. Ibid., xxi.

31. Dallaire and Beardsley, Shake Hands, 181-3.

32. United Nations Department of Peacekeeping Operations, Handbook on United Nations Multidimensional Peacekeeping Operations (New York: United Nations, 2003), 68.

33. Gérard Prunier, The Rwanda Crisis: History of a Genocide (New York: Columbia University Press, 1997), 83.

34. Prunier, Rwanda Crisis, 90

35. Dallaire and Beardsley, Shake Hands, 47-8.

36. Melvern, A People Betrayed, 53.

37. Herman J. Cohen, Intervening in Africa: Superpower Peacemaking in a Troubled Continent (Houndmills, Basingstoke, Hampshire: Macmillan; New York: St. Martin's, 2000), 176.

38. Off, The Lion, the Fox \& the Eagle, 26.

39. Jocelyn Coulon, Phyllis Aronoff, and Howard Scott, Soldiers of Diplomacy: The United Nations, Peacekeeping, and the New World Order (Toronto: U of Toronto P, 1998), 169.

40. Booh-Booh, Le patron, 38.

41. Cobbald, “Interview," 26.

42. United Nations Deptartment of Peacekeeping Operations and Department of Field Support, United Nations Peacekeeping Operations: Principles and Guidelines (New York: United Nations, 2008).

43. David A. Hamburg, Preventing Genocide: Practical Steps Toward Early Detection and Effective Action (Boulder, CO: Paradigm, 2008), 69.

44. Off, The Lion, the Fox \& the Eagle, 36.

45. Dallaire and Beardsley, Shake Hands, 54. 
46. United Nations Department of Public Information, The United Nations and Rwanda, 1993-1996, United Nations Blue Books Series 10 (New York: United Nations, 1996), 207, 211.

47. Cobbald, "Interview," 26.

48. Melvern, A People Betrayed, 5.

49. Dallaire and Beardsley, Shake Hands, 75-6.

50. Ibid., $96-7$.

51. OECD et al., Soldiers to the Rescue, 78.

52. Ibid., 89.

53. Ibid., 89 .

54. Elizabeth Neuffer, The Key to My Neighbor's House: Seeking Justice in Bosnia and Rwanda (New York: Picador, 2001), 349.

55. OECD et al., Soldiers to the Rescue, 14; Jonathan Moore, Hard Choices: Moral Dilemmas in Humanitarian Intervention (Boulder, CO: Rowman \& Littlefield, 1998), 77.

56. Alain Destexhe, Rwanda, essai sur le génocide [Rwanda and genocide in the twentieth century] (New York: New York UP, 1995), 52; Jean Hatzfeld, Une Saison de machettes: récits [Machete season: The killers in Rwanda speak; a report] (New York: Farrar, Straus and Giroux, 2005), 15.

57. Hatzfeld, Saison de machettes, 15.

58. Fred Grünfeld and Anke Huijboom, The Failure to Prevent Genocide in Rwanda: The Role of Bystanders (Boston: Martinus Nijhoff, 2007), 253.

59. Melvern, A People Betrayed, 72.

60. Hamburg, Preventing Genocide, 68.

61. Hatzfeld, Saison de machettes, 58.

62. Off, The Lion, the Fox \& the Eagle, 94-5.

63. Ibid.

64. Anyidoho, Guns over Kigali, 93.

65. Paul J. Magnarella, "The Background and Causes of the Genocide in Rwanda," Journal of International Criminal Justice 3,4 (2005): 813.

66. Moore, Hard Choices, 86; Coulon, Aronoff, and Scott, Soldiers of Diplomacy, 179.

67. Melvern, A People Betrayed, 80; Grünfeld and Huijboom, Failure to Prevent, 39.

68. United Nations, United Nations and Rwanda, 232.

69. Off, The Lion, the Fox \& the Eagle, 33.

70. Coulon, Aronoff, and Scott, Soldiers of Diplomacy, 175.

71. Hamburg, Preventing Genocide, 217.

72. Cobbald, "Interview," 27.

73. Ibid., 28.

74. Off, The Lion, the Fox \& the Eagle, 33.

75. Cobbald, "Interview," 28.

76. Dallaire and Beardsley, Shake Hands, 96-7.

77. Melvern, A People Betrayed, 83-4.

78. Moore, Hard Choices, 74.

79. Off, The Lion, the Fox \& the Eagle, 38.

80. Moore, Hard Choices, 74.

81. Melvern, A People Betrayed, 83-4.

82. Dallaire and Beardsley, Shake Hands, 97.

83. Ibid., 131.

84. Ibid.

85. Ibid.

86. Douglas Anglin, Confronting Rwandan Genocide (Clementsport, NS: Canadian Peacekeeping, 2002), 14.

87. Off, The Lion, the Fox \& the Eagle, 38

88. Melvern, A People Betrayed, 87.

89. Scott Peterson, Me Against My Brother: At War in Somalia, Sudan, and Rwanda: A Journalist Reports from the Battlefields of Africa (New York: Routledge, 2000), 291.

90. Melvern, A People Betrayed, 101.

91. Off, The Lion, the Fox \& the Eagle, 27.

92. Ibid., 41.

93. Anyidoho, Guns over Kigali, 40

94. Off, The Lion, the Fox \& the Eagle, 41.

95. Moore, Hard Choices, 79; Anyidoho 48 
96. Dallaire and Beardsley, Shake Hands, 193.

97. Ibid., 84-5.

98. Melvern, A People Betrayed, 87.

99. Ibid., 94.

100. Off, The Lion, the Fox \& the Eagle, 27.

101. Melvern, A People Betrayed, 101.

102. Barbara Benton, ed., Soldiers for Peace: Fifty Years of United Nations Peacekeeping (New York: Facts on File, 1996), 39.

103. Off, The Lion, the Fox \& the Eagle, 37; Melvern, A People Betrayed, 100, 104.

104. Dallaire and Beardsley, Shake Hands, 179.

105. Anyidoho, Guns over Kigali, 11.

106. Cobbald, "Interview," 25-6.

107. Booh-Booh, 15.

108. Peterson, Me Against My Brother, 294; Off, The Lion, the Fox \& the Eagle, 38.

109. Melvern, A People Betrayed, 99.

110. Cobbald, "Interview," 26.

111. Anyidoho, Guns over Kigali, 19.

112. Ibid., 125.

113. Grünfeld and Huijboom, Failure to Prevent, 91.

114. Off, The Lion, the Fox \& the Eagle, 41-2.

115. Ibid., 41-2.

116. Grünfeld and Huijboom, Failure to Prevent, 97; Dallaire and Beardsley, Shake Hands, 144.

117. Off, The Lion, the Fox \& the Eagle, 43.

118. Ibid.; Dallaire and Beardsley, Shake Hands, 146.

119. Anglin, Confronting, 3.

120. Off, The Lion, the Fox \& the Eagle, 44; Grünfeld and Huijboom, Failure to Prevent, 108.

121. Melvern, A People Betrayed, 92-3.

122. Peterson, Me Against My Brother, 291.

123. Grünfeld and Huijboom, Failure to Prevent, 98.

124. Ibid., 122.

125. United Nations Department of Public Information, The United Nations and the Situation in Rwanda, Reference Paper (New York: United Nations, 1994), 5.

126. Grünfeld and Huijboom, Failure to Prevent, 123.

127. United Nations, Situation in Rwanda, 31. 